Int. J. Morphol.,

33(2):532-537, 2015.

\title{
Ultrastructure of the Thyroid Gland in Adult West African Dwarf Goat (Capra hircus)
}

\author{
Ultraestructura de la Glándula Tiroides en la Cabra Enana Africana Occidental (Capra hircus)
}

\author{
Igbokwe Casmir Onwuaso*; Ezeasor Daniel Nwagbo* \& Umar Mohammed Bello ${ }^{* * * * * *}$
}

IGBOKWE, C. O.; EZEASOR, D. N. \& UMAR, M. B. Ultrastructure of the thyroid gland in adult West African dwarf goat (Capra hircus). Int. J. Morphol., 33(2):532-537, 2015.

SUMMARY: The present study examined ultrastructure of the thyroid gland of adult West African Dwarf (WAD) goat in order to further understand the ultrastructural morphology and some of the changes in the components of the thyroid gland in goat with age. Thyroids glands obtained from fifteen adult WAD goats of different ages and sexes slaughtered at the local abattoirs were used in this study. Electron microscopic techniques were used to study the fixed tissue with emphasis on the follicular and parafollicular cells. The results showed that the ultrastructure is generally similar to that of some domestic animals. Follicular cells were cuboidal in young adult goats thyroids but were flattened in older goat thyroids of 5-7 years. These cells remarkably showed highly dilated cisternae of rough endoplasmic reticulum which decreased in frequency the older goats. Microvilli were short and sparse on the follicular cells and the number decreased in the older goats. Different sizes of apical vesicles of varying electron density were encountered that included colloid droplets, secretory vesicles and lysosome-like bodies and the appearance of these vesicles changed with age. Parafollicular cells were encountered in the basal position between follicular cells in all thyroids examined. Numerous dense cytoplasmic granules were observed and they were not apparently different from that described in several mammals.

KEY WORDS: Ultrastructure; Thyroid gland; Dwarf goat.

\section{INTRODUCTION}

The thyroid gland and thyroid hormones are important and central in mammalian development. Some human and animal studies showed that thyroid hormones play a crucial role in nervous, cardiovascular, immune and reproductive system development and function (Janini et al., 1993; Krassas, 2000). In mammalian development, the thyroid hormones have important effects on cell proliferation, differentiation and migration and its effects on growth and metabolism in all stages of mammalian development are well documented. The thyroid generally exhibits similar follicular structure, although there are certain gross, histological and ultrastructural variations amongst the species. Thyroid responses to environmental and nutritional influences do differ amongst domestic animals.

Available information on thyroid structure and development come mainly from invertebrates, murines (mouse, rat), reptiles, zebra fish and humans (Fujita, 1975; 1988; Van Vliet \& Polak, 2007; Rupik, 2011). Few published articles on thyroid morphology have considered domestic animals like goat (Roy et al., 1975, 1976; 1978a, 1978b; Baishya et al., 1985, 1986; Osuagwuh \& Aire, 1992; Adhikary et al., 2003; Bhardwaj et al., 2006). Even so, many of these studies were on gross anatomy, histology and morphometry of thyroid gland of exotic breeds of goats in the temperate and Mediterranean climate. There is no published work on the ultrastructure of the thyroid gland of the West African dwarf (WAD) goat. This breed of goat plays important roles in the diet and socio-economy of the people and traditional livestock farmers in West Africa. The objective of this study is to provide information on the ultrastructural features of the adult thyroid gland of WAD goat with emphasis on the follicular and parafollicular cells.

\section{MATERIAL AND METHOD}

Thyroids glands were obtained from fifteen (15) WAD goats of different ages and sexes slaughtered at the local abattoirs in Nsukka and Obollo Afor, Southern Nigeria.

\footnotetext{
* Department of Veterinary Anatomy, Faculty of Veterinary Medicine, University of Nigeria, Nsukka, Nigeria.

** Department of Anatomy and Physiology, Faculty of Veterinary Science, University of Pretoria, Onderstepoort, South Africa.

${ }^{* * *}$ Department of Veterinary Anatomy, Faculty of Veterinary Medicine, Ahmadu Bello University, Zaria, Nigeria.
} 
The age estimated by dentition (Solaiman, 2010), ranged from $1-7$ years.

Immediately after slaughter and excision of the thyroid lobes, small pieces of the organ were diced into $1 \mathrm{~mm} 3$ cubes and fixed in $2.5 \%$ glutaraldehyde in $0.12 \mathrm{M}$ Millonig's phosphate buffer at $\mathrm{pH}$ 7.4. They were post-fixed in $1 \%$ osmium tetroxide after rinsing in phosphate buffer for electron microscopy. The fixed pieces of the thyroid gland were dehydrated in graded ethanol, cleared in propylene oxide and embedded in epoxy resin. Ultra-thin sections (60$80 \mathrm{~nm}$ ) were collected on copper grids, stained with uranyl acetate, and counterstained with Reynold's lead citrate and they were examined under Philips CM10 transmission electron microscope accelerating at $80 \mathrm{KV}$ (FEI, Eindhoven, The Netherlands).

\section{RESULTS}

The profiles of small and large follicles at low magnification contained colloid in their lumen surrounded by follicular cells that varied in shape and size. Few parafollicular cells were basally located. The follicular cells appeared varied in their lateral and vertical dimensions. Most of these cells were cuboidal in shape. Low columnar cells were rare. Flat follicular cells were present in older thyroids and usually lined the larger follicle, whereas small follicles tend to have cells that were more cuboidal, suggesting therefore that the cell shape may be partly related to the amount of colloid in the lumen of each follicle (Fig. 1). The follicular cells were enclosed by a plasma membrane and

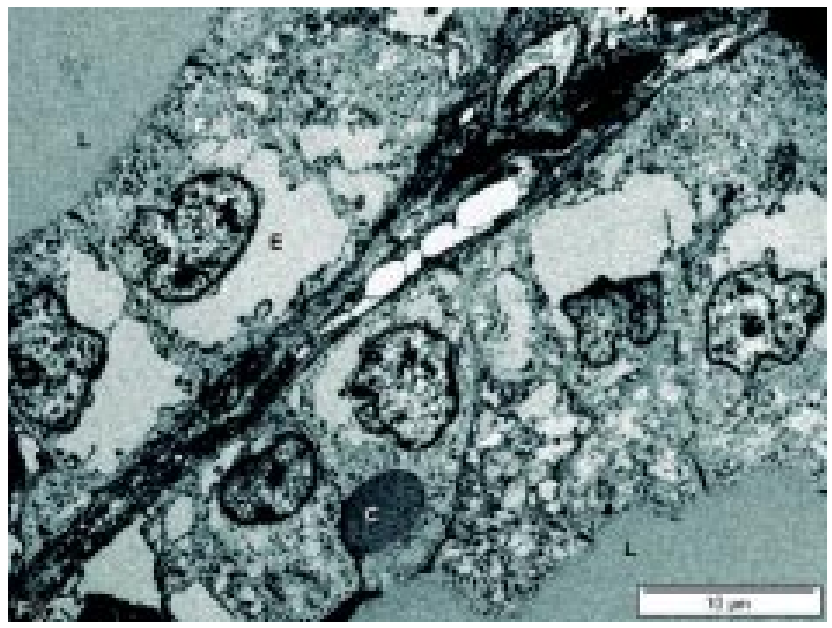

Fig. 1. Electron micrograph (EM) of follicular epithelia of thyroid of goat (1-2 years) showing cuboidal and columnar cells $(\mathrm{F})$ and parafollicular cell (P) and luminal colloid (L). Note colloid droplets (C), dilated cisterna of rough endoplasmic reticulum (RER) (E), nucleus $(\mathrm{N})$ and interfollicular connective tissue $(\mathrm{X})$. the basal part of the membrane was clearly defined without any modifications. The base of the follicular cells and the parafollicular cells rested on a distinct basement membrane. Junctional complexes were quite apparent between the two lateral membranes of follicular cells. It consisted of a tight junction, a gap junction, intermediate junction, desmosomes and septate junction (Fig. 2). The apical regions of the membrane were studded with few stubby microvilli that were apparently more in number in thyroids of $1-2$ years than in the older thyroids of 5-7 years. The interfollicular connective tissue spaces contained fine collagen fibrils and fibroblasts with slender processes.

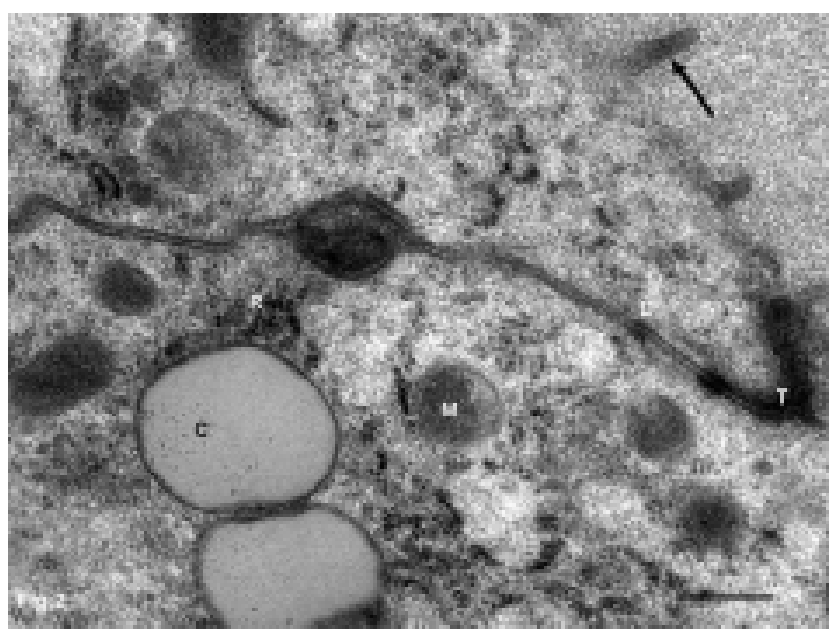

Fig. 2. EM micrograph of follicular cell showing typical intercellular junctional complex with tight junction (T), desmosome (D). Also present in the apical cell membrane a few short microvilli (arrow). Note mitchondria (M), colloid droplets (C) and free ribosomes in the cytoplasm.

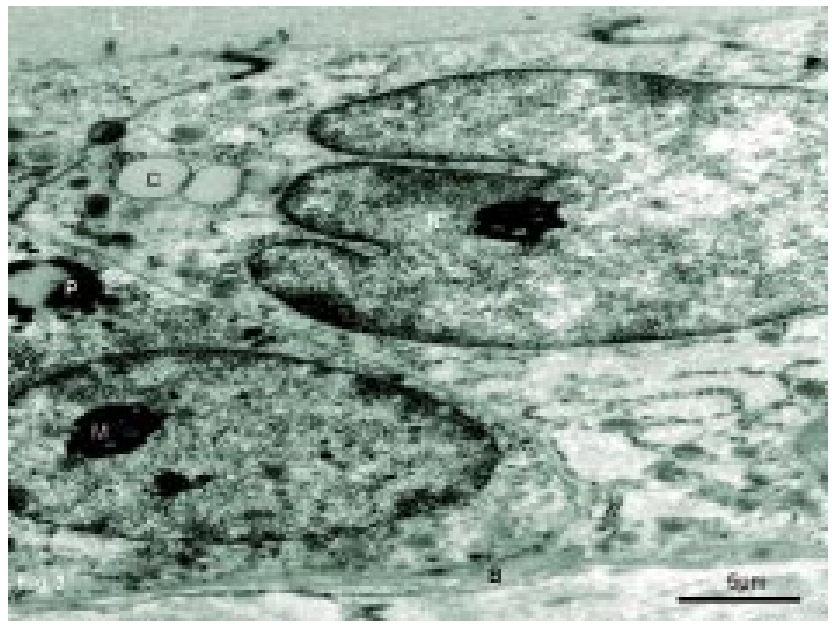

Fig. 3. EM micrograph of highly active follicular cells of thyroid gland of 3 year old goat showing indented nucleus $(\mathrm{N})$ and nucleoli (M), colloid drplets (C) and evidence of phagocytosis to release thyroid hormones from colloid droplets by dense lysosomes $(\mathrm{P})$. Note the basement membrane (B) and junctional complex (J). 
Microvilli were sparse, short and stubby in flat follicular cells of thyroids of 5-7 years. The microvilli on cuboidal cells of adult goats of 1-2 years were more numerous, thinner and distinctly finger-like. The nuclei localized basally, were heterochromatic in most of the cells. It maintained an irregular circular or elliptical shape with some indentations; the nuclei in some younger goats had lobe-like indentations (Fig. 3). It appeared the nuclei shapes were influenced by shape of the cell as well as the various cytoplasmic structures. In the flat cells, therefore the nucleus was flattened, while cuboidal cells contained more rounded nucleus. Nucleoli were prominent and surrounded partly by masses of heterochromatin in the sections examined. The cytoplasm of the follicular cell showed moderate numbers of mitochondria with varied shape that were mostly localized on the apical cytoplasm abutting the colloid and sometimes surrounded by membranes of the rough endoplasmic reticulum (RER) (Fig. 4).

Mitochondria appeared as round, oval, rod-shaped or dumbbell-shaped profiles and varied moderately in shape and size and irregular forms were present. Few free ribosomes were observed and somewhat irregularly distributed in the cytoplasm, some attached but most in small clusters. The cisternae of RER were highly dilated in thyroids of 1-3 years unlike in the older thyroids of 5-7 years. These profiles of RER were more localized in the basal and lateral aspect of the cytoplasm than in the apical cytoplasm. RER were visible as elongated, irregular, elliptical or sometimes circular profiles occupying a considerable portion of the cytoplasm. Cisternae were frequently close to the mitochondria and may occasionally completely surround them. Smooth endoplasmic reticulum was less conspicuous. Golgi complex were well- marked in thyroid sections of all

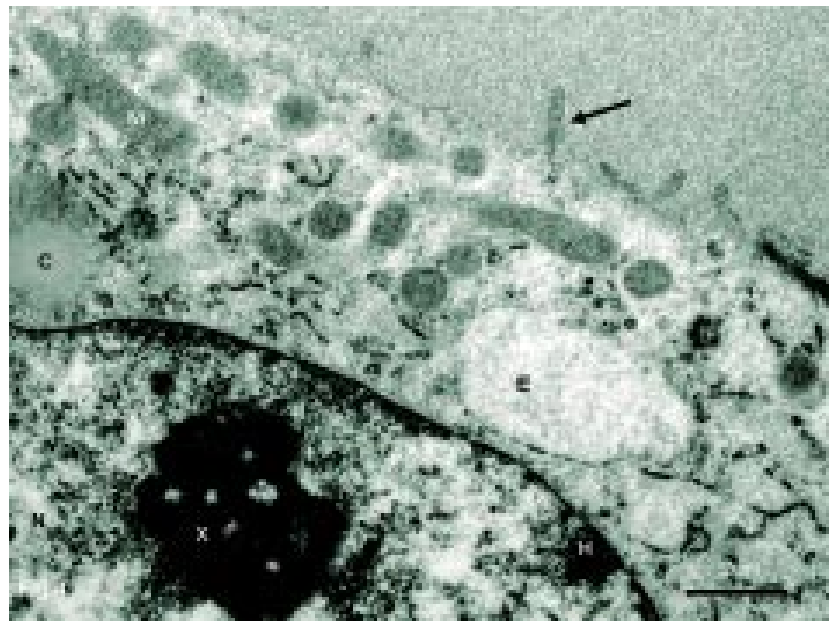

Fig. 4. EM micrograph of apical cytoplasm of follicular cell of goat ( 4 years) showing profiles of mitochondria (M), dilated RER (E), colloid droplets (C), microvilli (arrow), nucleus $(\mathrm{N})$ and nucleolus $(\mathrm{X})$ with marginal heterochromatin $(\mathrm{H})$. age and consisted of flattened sacs, vacuoles and small vesicles often lied beside or above the nucleus in some sections. The presence of large Golgi complex and colloid droplets commonly found in younger goats (1-2 years) were assumed as evidence of active secretion (Fig. 5). Three types of apically localized granular vesicles were present in the cytoplasm of follicular cells: small round and less dense, large vesicles assumed to becolloid droplets and small round dense bodies that were lysosome-like bodies. The small round and somewhat less dense vesicles were subapically located, while the large colloid droplets were also present with same electron density as the colloid. Small highly electron-dense granules presumed to be primary lysosomes were increased in number in the older thyroids of 5-6 years. In thyroid sections of 1-3 years, large colloid droplets were

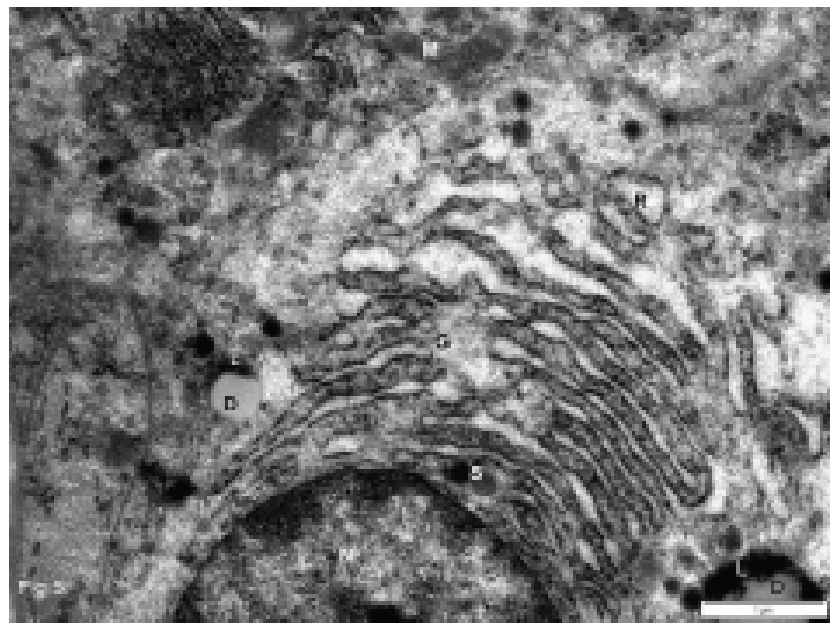

Fig. 5. EM micrograph of follicular cell of goat thyroid (3 years) showing Golgi stacks $(\mathrm{G})$ close to the nucleus $(\mathrm{N})$. Note abundant mitochondria (M), RER (R), secretory vesicles (S), colloid droplets (D) being phagocytosed by lysosomes (L) indicating activity.

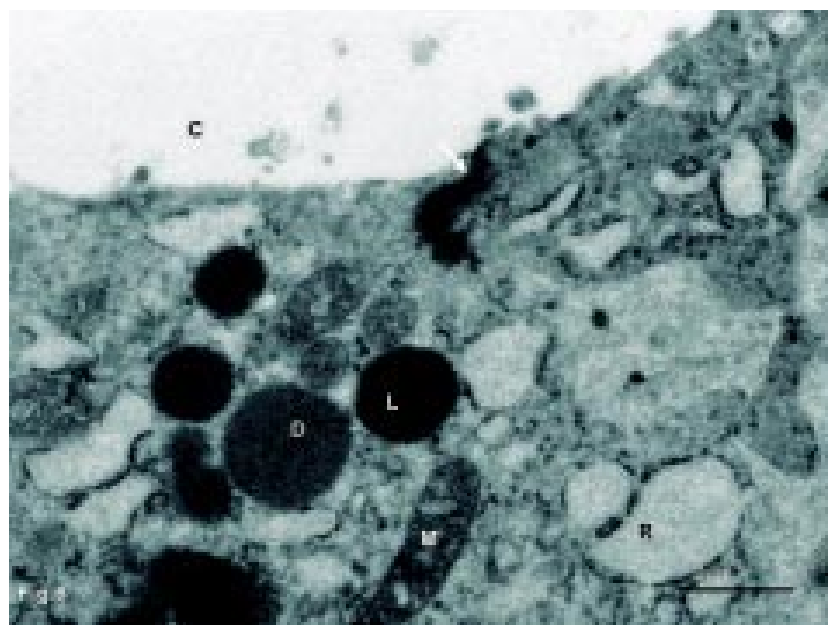

Fig. 6. EM micrograph of apical cytoplasm of follicular cells showing some organelles close to the colloid lumen (C). Note abundant mitochondria (M), RER (R), lysosomes (L), colloid droplets (D) and tight junctions (arrow) between cells. 
frequently observed to have fused with smaller dense granules (probably lysosomes) in sections signifying phagocytosis (pinocytosis) (Fig. 6). However in the older goats of 5-7 years, autophagic vacuoles and heterosomes of various sizes were commonly seen. Some cytoplasmic membrane structures probably multivesicular bodies which were round or irregular in shape were present in the cytoplasm but were more often near the Golgi complex.

Few parafollicular cells (C cells) were generally encountered in sections in the different ages and were positioned basally between two follicular cells, close to the basement membrane and never made contact with the follicular lumen (Fig. 7). Oval to round parafollicular cells were commonly observed, but in some older goats of 5-7

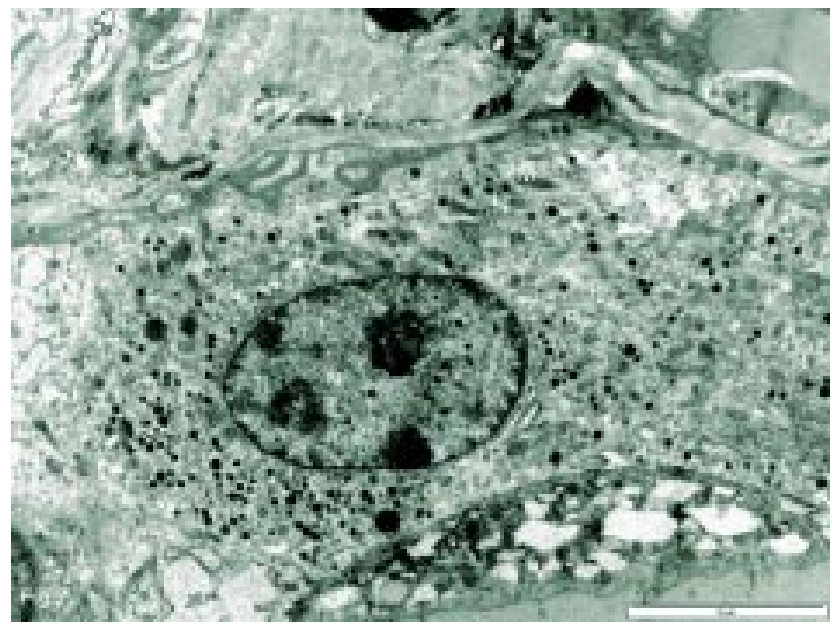

Fig. 7. EM micrograph of parafollicular cells of thyroid (2years goat) showing cytoplasm (P) with numerous dense secretory granules (S) and Golgi complex (G). Note the rim of cytoplasm of follicular cell (F) abutting the colloid.

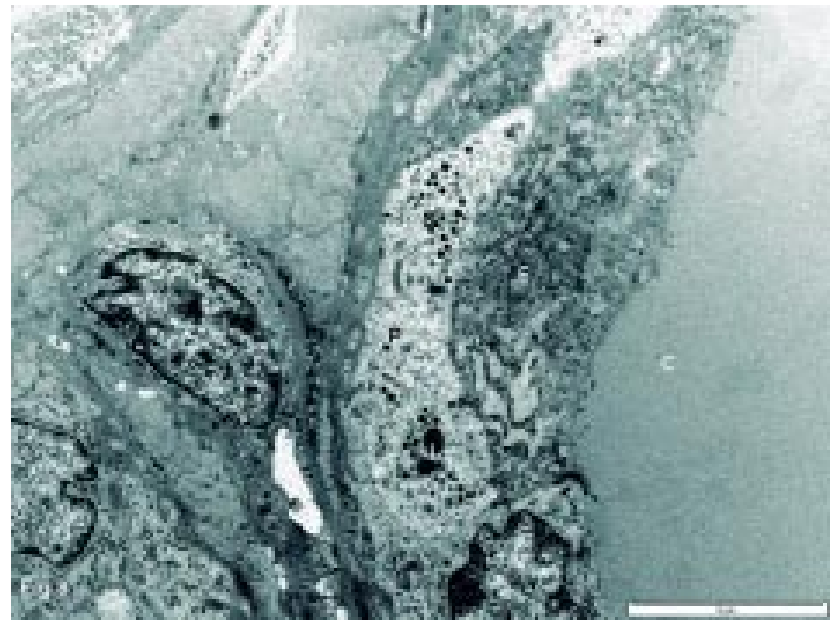

Fig. 8. EM micrograph of thyroid of goat (6 years) showing elongated parafollicular cells with numerous polarized dense granules amongst other organelles. Note thin rim of cytoplasm of follicular cells (F) close to follicular colloid (C). years elongated variety was equally present (Fig. 8). They generally showed oval nuclei, numerous dense secretory granules of varied size and electron density, abundant mitochondrial profile and scant rough endoplasmic reticulum in the cytoplasm. Parafollicular cells appeared to have increased in number of dense secretory granules with age. Lysosome-like bodies, autophagic vacuoles and residual bodies were also observed in these cells with advanced age of 5-7 years (Fig. 9).

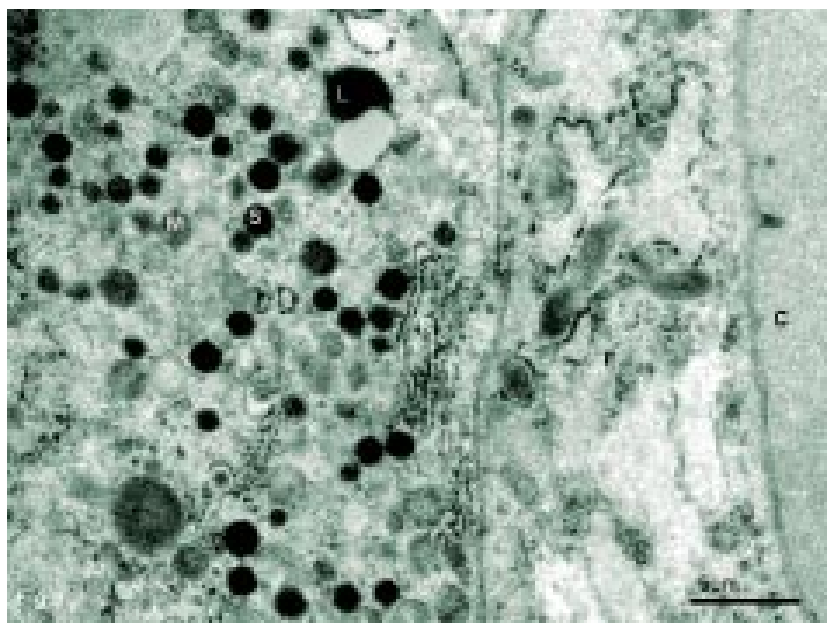

Fig. 9. EM micrograph of parafollicular cell showing numerous organelles in the cytoplasm that included mitochondria (M), dense secretory granules (S), lysosomes (L). Note the thin rim of follicular cell (F) cytoplasm abutting the colloid lumen (C).

\section{DISCUSSION}

The general ultrastructural features of the WAD goat thyroid are similar to that of several mammals (Irie, 1960; Fujita, 1975) in terms of the presence of follicular cells, parafollicular cells and their cytoplasmic organelles with minor variations observed in goats. These variations may be due to species and climatic differences. The thyroid of goat possesses features as seen in some domestic animals studied like sheep, camel (Abdel-Magied et al., 2000; Mubarak \& Sayed, 2005). These features included the presence of few stunted microvilli, highly dilated cisternae of rough endoplasmic reticulum and abundance of apical vesicles, colloid droplets and lysosomes in the cytoplasm of follicular cells. These organelles varied in number and size with advancing age of the goats as has been observed in some mammals (Fujita, 1975). Few stunted microvilli observed in the younger goat thyroid decreased in the advanced goat of 7 years made of predominantly flattened follicular cells, suggesting decreased endocytic activity. The number and size varies with species and also in experimen- 
tal or pathological conditions. It is relatively rare in many species of lower vertebrates such as dogfish and stingray (Fujita, 1975); but it is present in the lamprey. Studies have shown that microvilli of thyroid follicular cells phagocytose colloid from follicular lumina so that thyroid hormones formed on the scaffold of thyroglobulin can be processed intracellularly and released into circulation (French \& Hodges, 1977). Electron dense granules noted in the apical cytoplasm of follicular cells in all goat thyroids increased in the older goats showed close resemblance to structures described as lysosomes by Wollman (1969). Fusions of colloid droplets and lysosomes observed in this study have emphasized the functional role of lysosomes in the release of thyroid hormones from thyroglobulin in the colloid droplets.

The organelles most frequently observed in the present study of the high cuboidal follicular cells of hyperactive stage of younger goats thyroids of 1-3 years included secretory vesicles, microvilli, cisternae of RER, colloid droplets, mitochondria (often closely associated to RER), Golgi complexes, primary lysosomes and secondary lysosomes. The importance of these features is that, they are the organelles required for optimum production of thyroid hormones from protein synthesized from the follicular cells. According to Fujita (1988) and Abdel-Magied et al., the presence of Golgi complexes, RER and secretory vesicles indicate the activity of follicular cells in the synthesis and secretion of thyroglobulin towards the follicular lumen. The close association of mitochondria to cisternae of RER, observed in the present study, indicate increased activity of the follicular cells in the synthesis of thyroglobulin (Gorbman et al., 1983). The secretory granules, containing thyroglobulin are produced in the Golgi complex and move towards the apical plasma membrane, where they release their contents by exocytosis into the follicular lumen (Kameda et al., 1986).
The present study showed the existence of few parafollicular cells that were mainly single and basally located (parafollicular position) in relation to follicular cells, such location is similar to that in the thyroids of adult pig and cattle (Igbokwe, 2013). In hamsters some of the cells occupy an epifollicular position, while others are wedged between follicular cells and in Sprague-Dawley rats are present in intrafollicular or interfollicular positions as in the human adult (Hwang et al., 1986). The present study has shown species similarities in the location of parafollicular cells.

One or two of such cells were frequently encountered per follicle. This is different from other mammals such as cat, dog, rabbit and rat were they are numerous (Lupulescu \& Petrovici, 1968) and in deer thyroid (Pantic, 1967) and many mammalian hibernators, but they are very rare in many primates including human thyroids (Nunez \& Gershon, 1978). The role of parafollicular cells in calcium metabolism through calcitonin in most mammals studied is most likely similar in WAD goats.

In conclusion, the study showed that the ultrastructure thyroid of WAD goats does bot differ remarkably from that of mammalian species and that it is highly active at least in the younger goats. This activity may be reduced in advanced age because of age-related changes in the cellular organelles. Therefore care must be exercised in the interpretation of morphological changes in thyroids of WAD goats in pathological and toxicological conditions.

ACKNOWLEDGEMENTS. Mrs. Erna Van Wilpe and Lizette Du Plessis of the Electron Microscopic Unit, Dept. of Veterinary Anatomy/Physiology, Faculty of Veterinary Science (University of Pretoria, South Africa) for their technical support.

IGBOKWE, C. O.; EZEASOR, D. N. \& UMAR, M. B. Ultraestructura de la glándula tiroides en la cabra enana africana occidental (Capra hircus). Int. J. Morphol., 33(2):532-537, 2015.

RESUMEN: El presente estudio examinó la ultraestructura de la glándula tiroides en cabra enana de África occidental adulta con el objetivo de tener un mejor conocimiento de la morfología y algunos de los cambios en los componentes de esta glándula en cabras de mayor edad. Se estudiaron glándulas tiroides obtenidas de quince cabras adultas de diferentes edades y sexos, sacrificadas en los mataderos locales. Se utilizaron técnicas de microscopía electrónica para estudiar el tejido con énfasis en las células foliculares y para foliculares. Los resultados mostraron que la ultraestructura generalmente era similar a la de algunos animales domésticos. Las células foliculares en la tiroides de cabras adultas jóvenes eran cúbicas, no obstante en cabras adultas de mayor edad ( 5 a 7 años) se observaron células aplanadas en las tiroides. Estas células mostraron cisternas de retículo endoplasmático rugoso muy dilatadas que disminuyeron en frecuencia en las cabras de más edad. Las microvellosidades eran cortas y escasas en las células foliculares, y el número disminuyó en las cabras de más edad. Se encontraron diferentes tamaños de vesículas apicales y se observaron gotitas coloidales, vesículas secretoras y organismos similares a los lisosomas; la aparición de estas vesículas fue cambiando en cabras de mayor edad. Se encontraron células parafoliculares en posición basal en todas las células foliculares examinadas. Se observaron numerosos gránulos citoplasmáticos densos sin aparente diferencia de aquellos descritos en otros mamíferos.

PALABRAS CLAVE: Ultraestructura; Glandula tiroides; Cabra enana. 


\section{REFERENCES}

Abdel-Magied, E. M.; Taha, A. A. \& Abdalla, A. B. Light and electron microscopic study of the thyroid gland of the camel (Camelus dromedarius). Anat. Histol. Embryol., 29(6):331-6, 2000.

Adhikary, G. N.; Quasem, M. A.; Das, S. K. \& Khalil, M. A prospective study on histochemical observations of thyroid of pubertal black Bengal goat. Mymensingh Med. J., 12(2):108-11, 2003.

Baishya, G.; Ahmed, S. \& Bhattacharya, M. Gross anatomical observations on male-gonad and thyroids gland in Assam goat (Capra hircus) during post-natal life (zero to ninety days). Ind. Vet. J., 62:395-400, 1985.

Baishya, G.; Ahmed, S. \& Bhattacharya, M. Histomorphological and histochemical study of thyroid gland of prepubertal Assam goat. Short communication. Guwahati, Assam Agricultural University, 1986.

Bhardwaj, R. L.; Rajput, R.; Pathak, V. \& Thakur, K. Comparative anatomy of the thyroid of small ruminants. Ind. J. Anim. Sci., 76(1):46-7, 2006

French, E. I. \& Hodges, R. D. Fine structural studies on the thyroid gland of the normal domestic fowl. Cell Tissue Res., 178(3):397410, 1977.

Fujita, H. Fine structure of the thyroid gland. Int. Rev. Cytol., 40:197$280,1975$.

Fujita, H. Functional morphology of the thyroid. Int. Rev. Cytol., 113:145-85, 1988.

Gorbman, A. W.; Dickhoff, W. W.; Vigna, S. R.; Clark, N. B. \& Ralph, C. L. Comparative Endocrinology. New York, John Wiley \& Sons, 1983. pp.185-276.

Hwang, Y.; Lee, B. L.; Cha, C. I.; Chang, K. Y.; Lee, K. H. \& Seoung, K. J. An immunocytochemical study on the development and growth of C-cells in the rat thyroid. Seoul J. Med., 27(4):297-305, 1986.

Igbokwe, C. O. Comparative morphology of the thyroid gland at various stage of development in some domestic animals. $\mathrm{PhD}$ Thesis. Nsukka, University of Nigeria, 2013.

Irie, M. Electron microscopic observation on the various mammalian thyroid glands. Arch. Histol. Jpn., 19:39-74, 1960.

Janini, E. A.; Ulisse, S.; Piersanti, D.; Carosa, E.; Muzi, P.; Lazar, J. \& D'Armiento, M. Early thyroid hormone treatment in rats increases testis size and germ cell number. Endocrinology, 132(6):27268,1993 .

Kameda, Y.; Udatsu, K.; Horino, M. \& Tagawa, T. Localization and development of immunoreactive triiodothyronine in thyroid glands of dogs and chickens. Anat. Rec., 214(2):168-76, 1986.

Krassas, G. E. Thyroid disease and female reproduction. Fertil. Steril., 74(6):1063-70, 2000.
Mubarak, W. \& Sayed, R. Ultramicroscopical study on thyrocalcitonin cells in the camel (Camelus dromedarius). Anat. Histol. Embryol., 34(Suppl. 1):35, 2005.

Lupulescu, A. \& Petrovici, A. Ultrastructure of the thyroid gland. Baltimore, Williams \& Wilkin, 1968.

Nunez, E. A. \& Gershon, M. D. Cytophysiology of thyroid parafollicular cells. Int. Rev. Cytol., 52:1-80, 1978.

Osuagwuh, A. I. A. \& Aire, T. A. The growth rates of fetal thyroid, pituitary and adrenal glands of the West African dwarf goat. Anim. Reprod. Sci., 27(1):31-9, 1992.

Pantic, V. Ultrastructure of deer and roe-buck thyroid. Z. Zellforsch. Mikrosk. Anat., 81(4):487-500, 1967.

Roy, K. S.; Saigal, R. P. \& Nanda, B. S. Gross histomorphological and histochemical changes in the thyroid gland of goat with age. I. Cross and biometric study. Anat. Anz., 137(5):479-85, 1975.

Roy, K. S.; Saigal, R. P.; Nanada, B. S. \& Nagpal, S. K. Gross, histomorphological and histochemical changes in the thyroid gland of goat with age. III. Occurrence of thymic tissue. Anat. Anz., 139(12):158-64, 1976.

Roy, K. S.; Saigal, R. P; Nanda, B. S. \& Nagpal, S. K. Gross, histomorphological and histochemical changes in thyroid gland of goat with age. II. Occurrence of ultimobranchial follicles. Anat. Anz., 143(1):72-85, 1978a.

Roy, K. S.; Saigal, R. P.; Nanda, B. S. \& Nagpal, S. K. Gross, histomorphological and histochemical changes in thyroid gland of goat with age. IV. Histomorphological study. Anat. Anz., 143(1):8695, 1978b.

Rupik, W. Structural and ultrastructural differentiation of the thyroid gland during embryogenesis in the grass snake Natrix natrix L. (Lepidosauria, Serpentes). Zoology (Jena), 114(20):284-97, 2011.

Solaiman, S. G. Goat Science and production. Iowa, Wiley-Blackwell, 2010. pp.88-97.

Van Valiet, G. \& Polak, M. Thyroid gland development and function. In: Savage, M. O. (Ed.). Endocrine development. Basel, Karger, 2007.

Wollman, S. H. Secretion of thyroid hormones. In: Dingle, T. T. \& Fell, H. B. (Eds.). Lysosomes in biology and pathology. Amsterdam, North-Holland Publishing Company, 1969. pp.495-9.

\section{Correspondence to:}

Igbokwe Casmir Onwuaso

Senior Lecturer

Department of Veterinary Anatomy

Faculty of Veterinary Medicine University of Nigeria

Nsukka

NIGERIA

Received: 05-12-2014

Accepted: 20-03-2015

Email: casmir.igbokwe@unn.edu.ng 